\title{
Norfloxacin - Tinidazole Suspension in Management of Infective Paediatric Diarrhoea (1-5 Years)
}

\author{
Dr Avinash Shankar ${ }^{1 *}$, Dr Shubham Roy², Dr Amit Kumar Singh ${ }^{3}$, Dr Amresh Shankar ${ }^{4}$, Dr \\ Anuradha Shankar \\ ${ }^{I}$ Chairman, National Institute of Health and Research, Warisaliganj ( Nawada), Bihar \\ ${ }^{2}$ Attending Consultant, Sitaram Bhartia Institute of Research and Science, Delhi \\ ${ }^{3}$ Associate Professor, Microbiology, TRIHMS, Naharlagun, Arunachal Pradesh \\ ${ }^{4}$ Bihar State Health Services, Govt. of Bihar \\ ${ }^{5}$ Senior Research Fellow, Regional Institute of Ayurvedic Research, Itanagar, Arunachal Pradesh
}

*Corresponding Author: Dr Avinash Shankar, Chairman, National Institute of Health and Research, Warisaliganj ( Nawada), Bihar

\begin{abstract}
Diarrhoea among children of 1-5 years remains a disease of high mortality and morbidity in spite of availability of various antidiarrheal constituting antimicrobial and antiprotozoal agent. Composite of Norfloxacin and Tinidazole $100 \mathrm{mg} / 5 \mathrm{ml}$ in dose of $10 \mathrm{mg} / \mathrm{Kg}$ every 12 hours in children of $1-5$ years in management of diarrhoea of varied clinical severity, dehydration status and etiopathogenesis proves worth without any untoward effects either suggestive of Norfloxacin Or Tinidazole.

In selected 569 children (307-male; 262-female), $13.7 \%$ were of age group 1-2 years while majority $35.5 \%$ were of age group 4-5 years. $01.2 \%$ presented with mixed infection, $29.4 \%$ Shigella species, $27.2 \%$ Salmonella and $18 \%$ with Giardia lambia. 50.6\%were presenting with fever, $27.4 \%$ dehydrated, $76.6 \%$ with irritability, $19.6 \%$ with Oliguria and 1.8\% with Anuria. Among all, 4 were mild dehydrated, 30 with moderate and 122 with severe dehydration and rest 413 were without dehydration. As per clinical status 169, 244 and 156 were of mild, moderate and severe clinical severity. Out of all 56, 78, and 87 had change in faecal consistency after 4 hours of therapy respectively while all severe cases by 12 hours though mild and moderate by 16 hrs. After 4 hrs of drug administration, 45 (26.6\%) mild cases, 116 (47.5\%) moderate cases and 56 (35.89\%) severe cases show decline in frequency of stool (3-4/day), while all cases of mild and severe cases taken 16 hours and moderate cases 20 hours. $6(3.5 \%), 8(3.2 \%)$ and 4 (2.56\%) of mild, moderate and severe cases had formed stool after 8 hours of drug administration, while all cases of mild, moderate and severe cases taken 28 hours, 32 hours and 20 hours, respectively. No patient showed any drug adversity, sequel or post therapy sequel or any quinolone related adversity in 3 years post therapy follow up.
\end{abstract}

\section{INTRODUCTION}

Diarrhoea the greatest killer of children worldwide and infective diarrhoea is very common during 1-5 years of age due to beginning of artificial food and drink from milk, predominating food and water borne diseases. Self-medication with OTC products or treatment by rural practitioners who prescribe therapeutics as per advise of the chemist and commonly prescribed composites are Colistin sulphate, Ofloxacin and Ornidazole, Cotrimoxazole, Metronidazole, Tinidazole and even Levofloxacin . Sometime Co-trimoxazole presents with its sulpha moiety adversity.

In India, acute diarrhoea cost 13\% of children life in age group 1-5 years, and protozoal and microbial infections pose serious and dreaded outcome not merely due to dehydration but due to bacterial septicaemia. Other commonest cause of diarrhoea is Rotavirus that makes the normal commensal Escherichia coli pathogenic and invite super infection. Though children are immunised against various diseases but diarrhoea remain unchecked. In addition, hygienic status and water quality poses increased threat.(1)

For prompt diarrhoeal management we need -

- A potent broad-spectrum antimicrobial agent to cover causative pathogen. 
- Remain maximum time in the intestinal lumen to ensure bacterial eradication, not only to ensure early cure but also to check diseases epidemics.

- Antimicrobial must be excreted through renal pathway to ensure minimum inhibitory concentration to check post-diarrhoeal UTI due to migration of normal commensal Escherichia coli.

- Anti-diarrhoeal composites should not pose any life threatening adversity.

Presently most commonly practiced broad spectrum antimicrobial acting on DNA is quinolone and WHO has recommended Ciprofloxacin in life threatening condition,. In the market preparations constituting quinolones are very common i.e- Ofloxacin and Ornidazole, Levofloxacin and Secnidazole, preparations with Metronidazole and Norfloxacin is being marketed presently by more than 15 pharma company in India but is an irrational combination of varied biological half-life posing either over dose or under dose being withdrawn .

Norfloxacin, a primary quinolone with low plasma protein binding and volume distribution than Ciprofloxacin, Levofloxacin and Ofloxacin having maximum stay in GIT lumen and excreted through Urinary path way with no quinolone adversity as was evident with Metronidazole -Norfloxacin prescription as an anti-diarrhoeal for years.

To curb the dreaded infective diarrhoea a combination of Tinidazole and Norfloxacin been evaluated in treatment of infective diarrhoea with vigil watch on quinolone adversity.

\subsection{Objective of the Study}

To ascertain clinical efficacy and safety profile of Tinidazole and Norfloxacin combination therapy in infective diarrhoea among children of 1-5 years age.

\subsection{Duration of Study}

March 2014-2015 with post therapy follow up for 4 years to ascertain quinolone generated any adversity i.e. from February 2015 to March 2019.

\subsection{Ethical status}

Ethical committee recommended study to affirm the safety profile and therapeutic efficacy of primary quinolones used since long as a combination with various anti protozoal drugs.

\section{MATERiAl \& MethodS}

\subsection{Material}

Patients of infective diarrhoea enrolled at Centre For Research in Diarrhoeal Disease of National Institute of Health \& Research, Warisaliganj (Nawada), Bihar during March 2014 to February 2015 were selected for the assessment of therapeutic efficacy and safety profile of the combination of Tinidazole Suspension and Norfloxacin Suspension.

\subsection{Methods}

Parents of selected patients were thoroughly interrogated for history of onset of diarrhoea, duration, frequency, associated manifestations like vomiting, fever, irritability, excessive crying, craving for water, urine output, clinically examined for hydration status and other findings to classify the patients as per severity, investigated for stool culture and routine, urine routine and culture, serum electrolyte, haematological, hepatic and renal status.

For hydration status Patients were indexed as per -

\begin{tabular}{|l|l|}
\hline $\begin{array}{c}\text { Dehydration } \\
\text { status }\end{array}$ & \multicolumn{1}{c|}{ Characteristics } \\
\hline Mild & Irritable, thirsty \\
\hline Moderate & $\begin{array}{l}\text { Irritable, weak pulse, reduced urine output Anterior fontanelle depressed, eyeball sunken, } \\
\text { face dry and parched lips and buccal mucosa dry, skin turgor lost thirsty. }\end{array}$ \\
\hline Severe & $\begin{array}{l}\text { Moribund, apathetic, pulse weak, thread Marked reduced in the urine volume Fontanelle } \\
\text { depressed, eye ball markedly sunken Lips parched, face markedly dried and pinched } \\
\text { Buccal mucosa dry, loss of skin turgor and thirsty. }\end{array}$ \\
\hline
\end{tabular}


Based on clinical presentation selected patients were graded for the disease severity as per following index -

\begin{tabular}{|l|l|}
\hline \multicolumn{1}{|c|}{ Degree of severity } & \multicolumn{1}{|c|}{ Characteristic features } \\
\hline Mild & $\begin{array}{l}\text { Lose motion with mucous without fowl smell Frequency of motion 5/day Mild } \\
\text { dehydration }\end{array}$ \\
\hline Moderate & $\begin{array}{l}\text { lose motion with mucous with fowl smell Frequency up to 10 /day Moderate } \\
\text { dehydration }\end{array}$ \\
\hline Severe & Watery fowl smelling stool Frequency >12/day Severe dehydration \\
\hline
\end{tabular}

Patients with poor hydration status been first rehydrated with paediatric intravenous fluid which contains Sodium, Potassium, Magnesium, Dibasic Potassium Phosphate and Hydrous dextrose in dose schedule of $-100 \mathrm{ml} / \mathrm{Kg}$ body weight, out of which $30 \mathrm{ml} / \mathrm{kg}$ in first 30 minutes, rest $30 \%$ in 1 hour and $40 \%$ in 2 hours to ensure urine output .

Patients of mild or moderate dehydration, be supplemented with Oral hydration fluid.

\subsection{Precautions}

- $\quad$ Sodium: $50 \mathrm{mEq} / \mathrm{L}$ (WHO ORS contains $75 \mathrm{mEq} / \mathrm{L}$, older formulations were $90 \mathrm{mEq} / \mathrm{L}$ )

- Dextrose: $25 \mathrm{~g} / \mathrm{L}$ (WHO ORS contains $13.5 \mathrm{~g} / \mathrm{L}$ or $75 \mathrm{mmol} / \mathrm{L}$ )

- Bicarbonate: $30 \mathrm{mEq} / \mathrm{L}$

$>$ In mild cases, half strength apple juice has been used safely and effectively

- Was followed by preferred fluids and resulted in better oral intake than with ORS

$>$ Avoid other solutions that do not adequately replace Sodium, bicarbonate, Potassium and Glucose

- Avoid hypo-osmolar fluids (water, sodas, and juices) due to Hyponatremia risk.

- Avoid adult ORS solutions due to risk of Hypernatremia risk.

\section{Mild Dehydration (standard replacement)}

Total ORS: $50 \mathrm{ml} / \mathrm{kg}$ over 4 hours by syringe, spoon or cup

Administer $1 \mathrm{ml} / \mathrm{kg}$ of ORS by syringe every 5 minutes for 4 hours or

Administer $3 \mathrm{ml} / \mathrm{kg}$ of ORS every 15 minutes for 4 hours

\section{Moderate Dehydration (accelerated replacement)}

Total ORS: $100 \mathrm{ml} / \mathrm{kg}$ over 4 hours or WHO age and weight specific recommendations

\begin{tabular}{|l|l|l|}
\hline \multicolumn{1}{|c|}{ Weight (Kg) } & \multicolumn{1}{|c|}{ Age (years) } & \multicolumn{1}{c|}{ Dose of ORS (ml) } \\
\hline $8-11$ & $1-2$ & $600-800$ \\
\hline $11-16$ & $2-5$ & $800-1200$ \\
\hline
\end{tabular}

Toddler Example (age 2): 600 to $800 \mathrm{ml}$ in 4 hours

Administer $>150 \mathrm{ml}(5 \mathrm{oz})$ per hour of ORS

Administer $15-30 \mathrm{ml}(0.5-1$ oz or $1-2 \mathrm{tbs})$ every 5-10 minutes

\section{Preschool Child Example (age 4): 800 to $1200 \mathrm{ml}$ in 4 hours}

Administer $>200 \mathrm{ml}(\sim 7 \mathrm{oz})$ per hour of ORS

Administer $30-45 \mathrm{ml}$ (1-1.5 oz or 2-3 tbs) every 5-10 minutes

Each selected patients were prescribed and administered -

Combination of Norfloxacin suspension and Tinidazole suspension in dose of - Tinidazole $10 \mathrm{mg} / \mathrm{Kg}$ and Norfloxacin $10 \mathrm{mg} / \mathrm{Kg}$ every 12 hours.

Patients were analysed for outcome of therapy i.e. - decrease in frequency of stool, time required for change in faecal matter consistency, formed stool, urine output, abdominal distension, excessive 
crying, and craving for water. In addition, post-diarrhoeal sequel like post diarrhoeal UTI, mucous colitis and nephritis .Post therapy stool culture, urine culture, haematological, hepatic and renal bio parameters were repeated to adjudge the safety profile.

For Quinolone related untoward effect every mother were given a follow up card to enter the onset of any of these symptom and contact the Centre For Diarrhoeal Disease Research for due needful, or attend every 3 months for $1^{\text {st }}$ year ,every 6 months in $2^{\text {nd }}$ year and after completion of $3^{\text {rd }}$ year for Quinolone generated adversity assessment. In addition, drug therapy during this period of follow up must be recorded.

Based on clinical response achieved therapeutic response was graded as per following index of achievement

\begin{tabular}{|l|l|}
\hline \multicolumn{1}{|c|}{ Clinical grades } & \multicolumn{1}{c|}{ Characteristics } \\
\hline Grade I (Excellent) & $\begin{array}{l}\text { Decline in frequency and change in consistency of Stool, formed stool in 12 hrs. } \\
\text { Recovery with minimal Water and electrolyte supplementation, reduced Duration of } \\
\text { illness and ultimately cost of therapy Without any drug or diseases related untoward } \\
\text { effect No reversal, No post therapy sequel }\end{array}$ \\
\hline Grade II (Good) & $\begin{array}{l}\text { Decline in frequency and change in consistency of stool in 48 hours, recovery on fluid } \\
\text { and electrolyte intravenous Supplementation, persistence of 2-4 lose motion daily } \\
\text { with post therapy sequel }\end{array}$ \\
\hline Grade III (Poor) & No response, worsening of diarrhoea \\
\hline
\end{tabular}

To assure dose adequacy and convenience in dose administration a molecular stability study had done for composite containing $100 \mathrm{mg}$ of Norfloxacin and $100 \mathrm{mg}$ Tinidazole in each $5 \mathrm{ml}$ of suspension or separately for Norfloxacin 100mg/5ml and Tinidazole 100mg/5ml (Courtesy Ripaurva)

\section{Dosing regimen for Racecadotril in infants (aged over 3 months) and children}

$1.5 \mathrm{mg} / \mathrm{kg}$ per dose

\begin{tabular}{|c|c|c|c|c|}
\hline Weight & Less than 9 kg & 9 kg to less than 13 kg & $\mathbf{1 3}$ to 27 kg & More than 27 kg \\
\hline Dose (3 times a day) & $10 \mathrm{mg}$ & $20 \mathrm{mg}$ & $30 \mathrm{mg}$ & $60 \mathrm{mg}$ \\
\hline Sachets per dose & $1 \times 10 \mathrm{mg}$ & $2 \times 10 \mathrm{mg}$ & $1 \times 30 \mathrm{mg}$ & $2 \times 30 \mathrm{mg}$ \\
\hline
\end{tabular}

\section{OBSERVATION}

Table1. Distribution of patients as per age \& sex

\begin{tabular}{|c|c|c|c|c|}
\hline \multirow{2}{*}{$\begin{array}{l}\text { Age group } \\
\text { (in years) }\end{array}$} & \multicolumn{4}{|c|}{ Number of patients } \\
\hline & Male & Female & Total & Percentage \\
\hline $1-2$ & 46 & 32 & 78 & 13.7 \\
\hline $2-3$ & 77 & 60 & 137 & 24.1 \\
\hline $3-4$ & 80 & 72 & 152 & 26.7 \\
\hline $4-5$ & 104 & 98 & 202 & 35.5 \\
\hline & 307 & 262 & 569 & \\
\hline
\end{tabular}

Selected 569 children were of age group 1-5 years, out of all $13.7 \%$ were of age group 1-2 years while majority $35.5 \%$ were of age group $4-5$ years (T-1)

Among 569 children, 307 were male and 262 female (Fig-1)

\section{Sex wise composition of the patients}

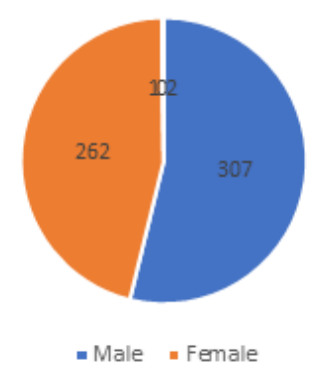

Figure1. Pie diagram showing sex wise composition 
Table2. Distribution of patients as per frequency of lose motion

\begin{tabular}{|l|l|l|}
\hline \multicolumn{1}{|c|}{ Frequency of motion } & \multicolumn{1}{c|}{ Number of patients } & \multicolumn{1}{c|}{ Percentage } \\
\hline 4-6/day & 109 & 19.2 \\
\hline 6-8/day & 204 & 35.8 \\
\hline 8-10/day & 189 & 33.2 \\
\hline$>10 /$ day & 67 & 11.8 \\
\hline
\end{tabular}

Out of all $19.2 \%$ children were presenting with 4-6 lose motion per day while majority $35.8 \%$ with 68 lose motion per day and $11.8 \%$ children $>10$ per day. (Table 2)

Table3. Distribution of patients as per causative pathogens

\begin{tabular}{|l|l|l|}
\hline \multicolumn{1}{|c|}{ Causative pathogens } & \multicolumn{1}{c|}{ Number of patients } & \multicolumn{1}{c|}{ Percentage } \\
\hline Giardia lamblia & 102 & 18.0 \\
\hline Proteus vulgaris & 138 & 24.2 \\
\hline Shigella species & 167 & 29.4 \\
\hline Salmonella & 154 & 27.2 \\
\hline Mixed infection & 08 & 01.2 \\
\hline
\end{tabular}

Out of all children admitted with lose motion $01.2 \%$ were with mixed infection, majority $29.4 \%$ Shigella species, $27.2 \%$ Salmonella and $18 \%$ with Giardia lambia. (Table 3)

Table4. Distribution of patients as per presentation

\begin{tabular}{|l|l|l|}
\hline \multicolumn{1}{|c|}{ Presenting features } & \multicolumn{1}{c|}{ Number of patients } & \multicolumn{1}{c|}{ Percentage } \\
\hline Lose motion with foul smell & 166 & 29.2 \\
\hline Lose motion with blood and mucous & 259 & 45.5 \\
\hline Watery motion & 87 & 15.3 \\
\hline Lose motion with excessive flatus & 57 & 10.0 \\
\hline Pain in abdomen & 569 & 100.0 \\
\hline Abdominal distension & 347 & 61.0 \\
\hline
\end{tabular}

Out of all $29.2 \%$ were presenting with lose motion with foul smell, $45.5 \%$ with lose motion with blood and mucous, $15.3 \%$ with watery motion, $10 \%$ with lose motion with excessive flatus. All presented with excessive crying due to abdominal pain and $61 \%$ with abdominal distension. (Table 4)

Table5. Distribution of patients as per bio parameters

\begin{tabular}{|c|c|c|}
\hline Bio parameters & Number of patients & Percentage \\
\hline \multicolumn{3}{|c|}{ HAEMATOLOGICAL } \\
\hline \multicolumn{3}{|l|}{ Haemoglobin: } \\
\hline$<10 \mathrm{gm} \%$ & 178 & 31.3 \\
\hline$>10 \mathrm{gm} \%$ & 391 & 68.7 \\
\hline \multicolumn{3}{|c|}{ HEPATIC } \\
\hline \multicolumn{3}{|l|}{ Serum Bilirubin: } \\
\hline$<1 \mathrm{mg} \%$ & 493 & 86.6 \\
\hline$>1 \mathrm{mg} \%$ & 76 & 13.4 \\
\hline \multicolumn{3}{|l|}{ SGOT: } \\
\hline$<35 \mathrm{IU}$ & 513 & 90.2 \\
\hline$>35 \mathrm{IU}$ & 56 & 9.8 \\
\hline \multicolumn{3}{|c|}{ RENAL } \\
\hline \multicolumn{3}{|l|}{ Urine Culture: } \\
\hline Positive & 98 & 17.2 \\
\hline Negative & 471 & 82.8 \\
\hline \multicolumn{3}{|l|}{ Blood Urea } \\
\hline$<20 \mathrm{mg} \%$ & 567 & 99.6 \\
\hline$>20 \mathrm{mg} \%$ & 02 & 0.4 \\
\hline \multicolumn{3}{|l|}{ Urine: } \\
\hline \multicolumn{3}{|l|}{ RBC } \\
\hline Present - & 02 & 0.4 \\
\hline Absent - & 567 & 99.6 \\
\hline \multicolumn{3}{|l|}{ Albumin: } \\
\hline Present - & 13 & 2.3 \\
\hline Absent - & 556 & 97.7 \\
\hline
\end{tabular}


Out of all 31.3\% were having haemoglobin less than 10 gram $\%$ while rest more than 10 gram $\%, 13.4 \%$ with serum bilirubin $>1 \mathrm{mg} \%, 9.8 \%$ with SGOT $>35 \mathrm{IU}, 17.2 \%$ with positive Urine culture, $0.4 \%$ with blood urea $>20 \mathrm{mg} \%, 0.4 \%$ show presence of $\mathrm{RBC}$ in the urine and $2.3 \%$ presence of albumin in the urine. (Table 5)

Table6. Distribution of patients as per lag period

\begin{tabular}{|l|l|l|}
\hline \multicolumn{1}{|c|}{ Lag period (in Hours) } & \multicolumn{1}{|c|}{ Number of patients } & \multicolumn{1}{c|}{ Percentage } \\
\hline $6-12$ & $112 \quad$ & 19.7 \\
\hline $12-18$ & 60 & 10.5 \\
\hline $18-24$ & 114 & 20.0 \\
\hline $24-30$ & 75 & 13.2 \\
\hline $30-36$ & 208 & 36.6 \\
\hline
\end{tabular}

Out of all majority $36.6 \%$ attended the Centre after $30-36$ hrs while $19.7 \%$ attended within 6-12 hours. (Table 6)

Table7. Distribution of patients as per clinical status

\begin{tabular}{|l|l|l|}
\hline \multicolumn{1}{|c|}{ Clinical status } & \multicolumn{1}{|c|}{ Number of patients } & \multicolumn{1}{c|}{ Percentage } \\
\hline Febrile & 238 & 50.6 \\
\hline Dehydrated & 156 & 27.4 \\
\hline Anuria & 10 & 1.8 \\
\hline Oliguria & 112 & 19.6 \\
\hline 76.6 & Irritability & 436 \\
\hline
\end{tabular}

$50.6 \%$ were presented with fever, $27.4 \%$ dehydrated, $76.6 \%$ were presenting with irritability and $19.6 \%$ with Oliguria and $1.8 \%$ with Anuria. (Table 8)

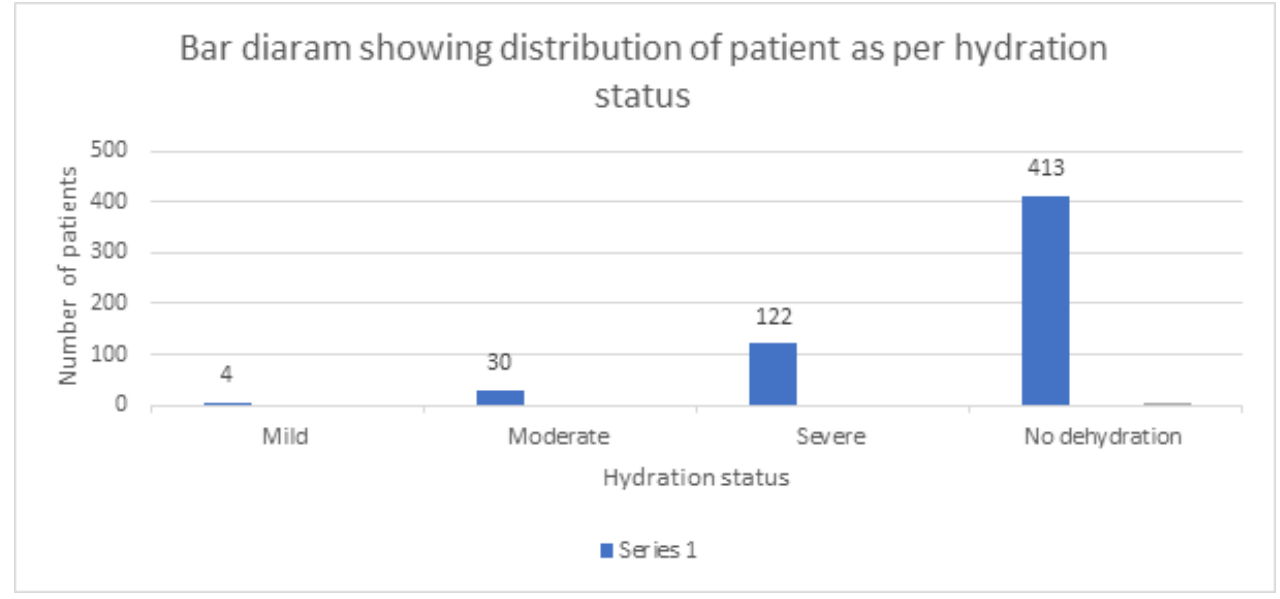

Figure 2: Bar diagram-showing distribution of patient as per hydration status

Out of all, 4 were mild dehydrated, 30 with moderate and 122 with severe dehydration and rest 413 were without dehydration. (Figure 2)

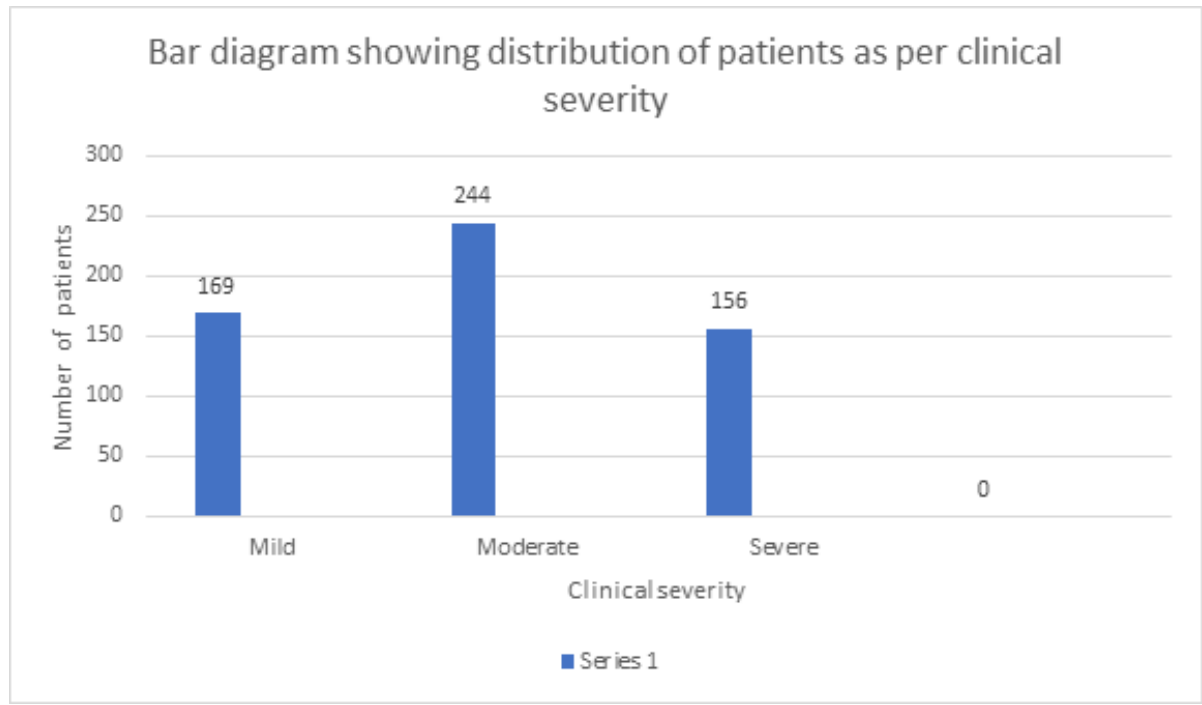

Figure 3: Bar diagram-showing distribution of patient as per clinical severity 
As per clinical status 169, 244 and 156 were of mild, moderate and severe clinical severity. (Figure 3)

\section{Results}

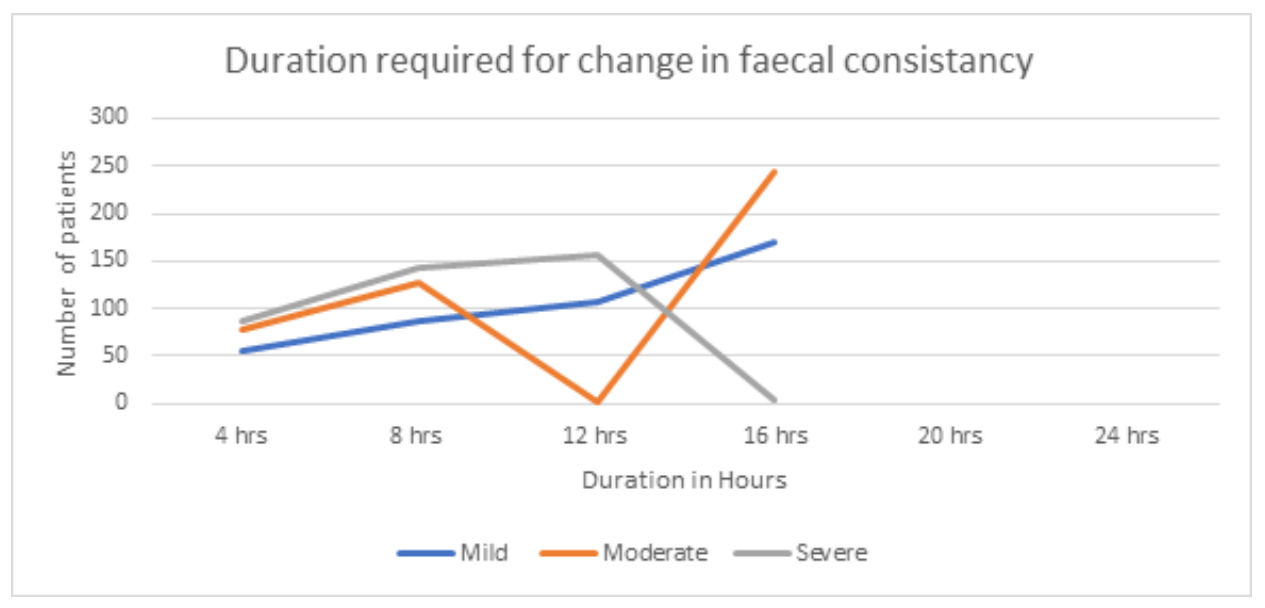

Figure4. Duration required for change in faecal consistancy

Out of all 56,78, and 87 had change in faecal consistency after 4 hours of therapy respectively while all severe cases by $12 \mathrm{hrs}$ though mild and moderate by $16 \mathrm{hrs}$. (Figure 4)

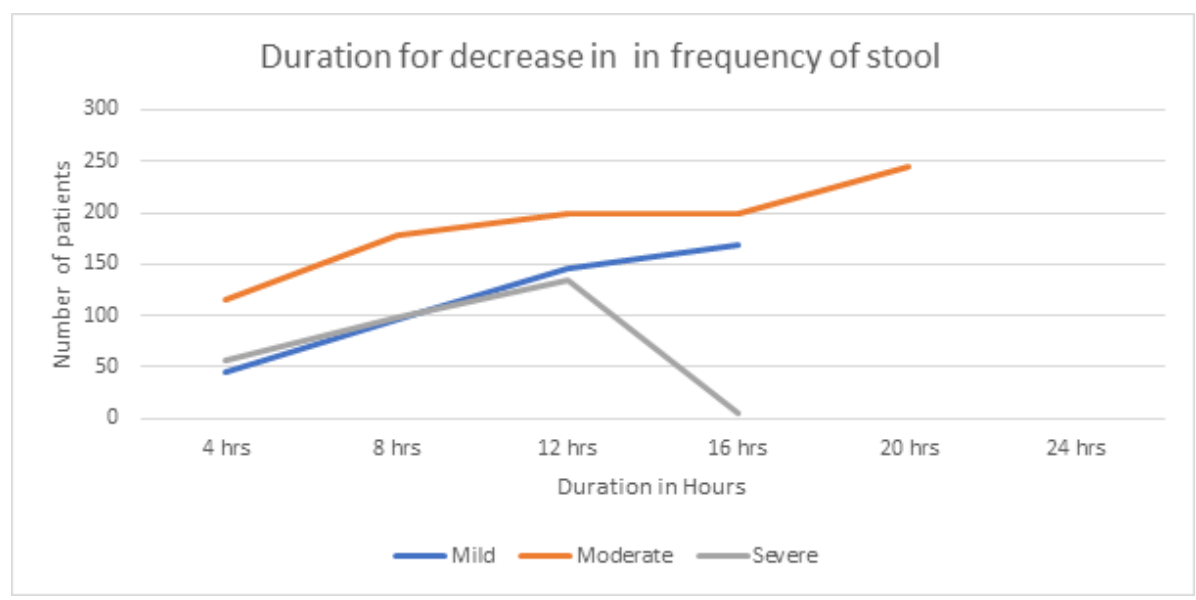

Figure5. Duration for decrease in frequency of stool

After 4 hours of drug administration 45 (26.6\%) mild cases, 116 (47.5\%) moderate cases and 56 (35.89\%) severe cases shows decline in frequency of stool (3-4/day) while all cases of mild and severe taken 16 hours and moderate one 20 hours. (Figure 5)

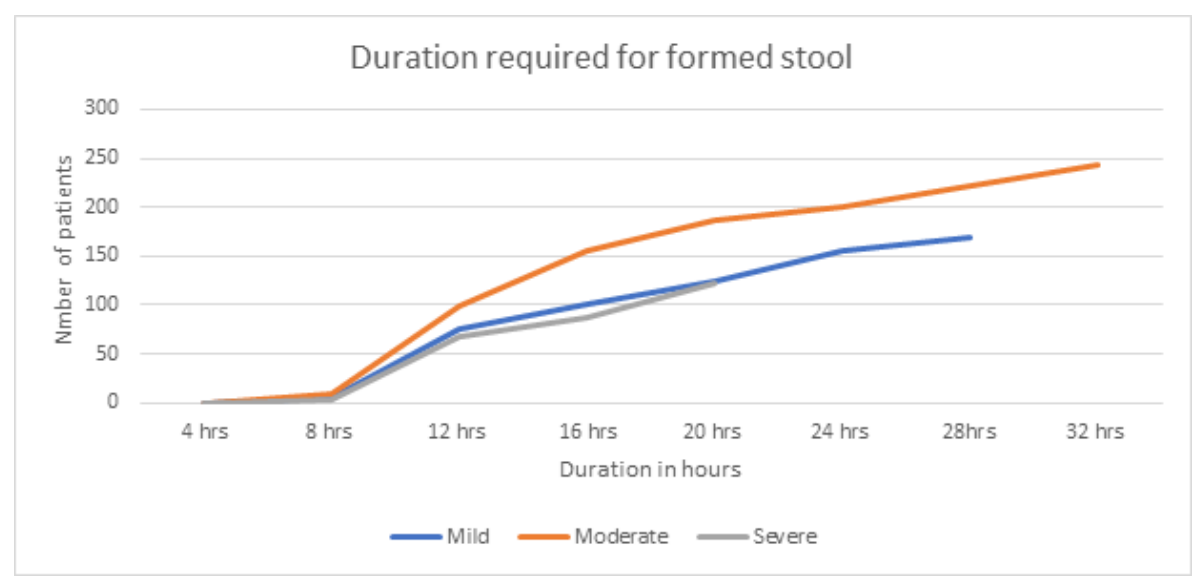

Figure 6: Duration required for formed stool

$6(3.5 \%), 8(3.2 \%)$ and 4 (2.56\%) of mild, moderate and severe cases had formed stool after 8 hours of drug administration while all cases of mild, moderate and severe cases taken 28 hours, 32 hours and 20 hours respectively . 
Table8. Outcome of study

\begin{tabular}{|c|c|c|}
\hline Particulars & Number of the patients & Percentage \\
\hline \multicolumn{3}{|c|}{ HYDRATION STATUS } \\
\hline Improved & 569 & 100 \\
\hline Worsened & nil & \\
\hline Unaltered & nil & \\
\hline \multicolumn{3}{|c|}{ UNTOWARD EFFECT /SEQUEL } \\
\hline Abdominal distension & none & \\
\hline Vomiting & none & \\
\hline Irritability & none & \\
\hline \multicolumn{3}{|c|}{ GRADES OF CLINICAL CURE } \\
\hline Grade I & 567 & 99.6 \\
\hline Grade II & 02 & 0.4 \\
\hline Grade III & nil & \\
\hline \multicolumn{3}{|c|}{ POST THERAPY SEQUEL } \\
\hline Mucous Colitis & none & \\
\hline Urinary tract infection & none & \\
\hline \multicolumn{3}{|c|}{ QUINOLONE GENERATED ADVERSITY } \\
\hline Cartilaginous osteo-arthropathy & none & \\
\hline Tendinitis and tendon rupture & none & \\
\hline Peripheral neuropathy & none & \\
\hline Central nervous system effects & none & \\
\hline
\end{tabular}

All patients had improved hydration status mild and moderate with oral rehydration while severe cases with intravenous hydration. $99.6 \%$ patients had grade I clinical response irrespective of their clinical severity and rest $0.4 \%$ grade II. No patient showed any drug adversity, sequel or post therapy sequel or any quinolone related adversity in 3 years post therapy follow up. (Table 8)

Both group i.e. Composite containing Tinidazole 100mg and Norfloxacin 100mg per 5ml Or Tinidazole $100 \mathrm{mg} / 5 \mathrm{ml}$ and Norfloxacin $100 \mathrm{mg} / 5 \mathrm{ml}$ separately as per chromatographic study. (Table 9)

Table9. Showing chromatographic pattern of both type of preparations

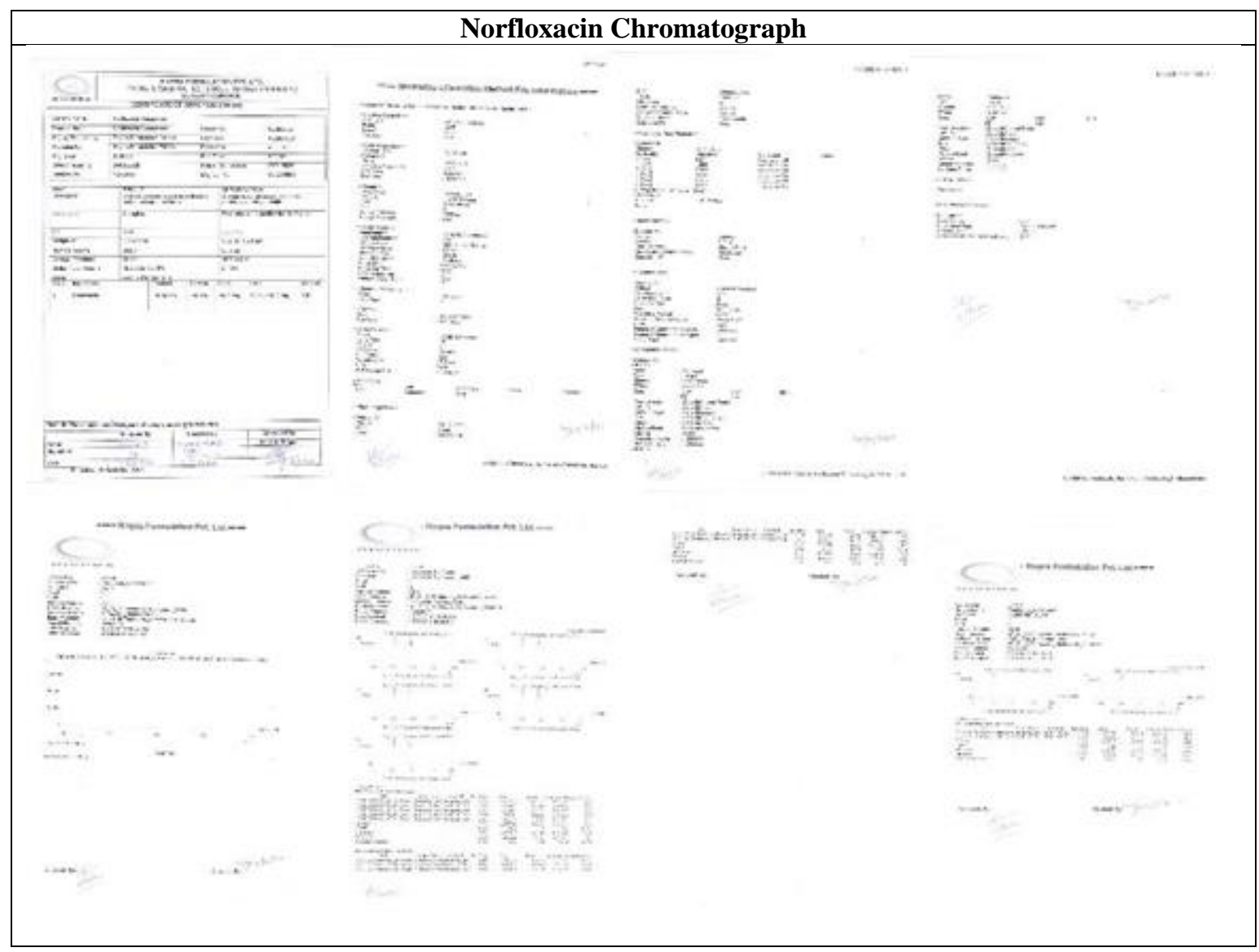




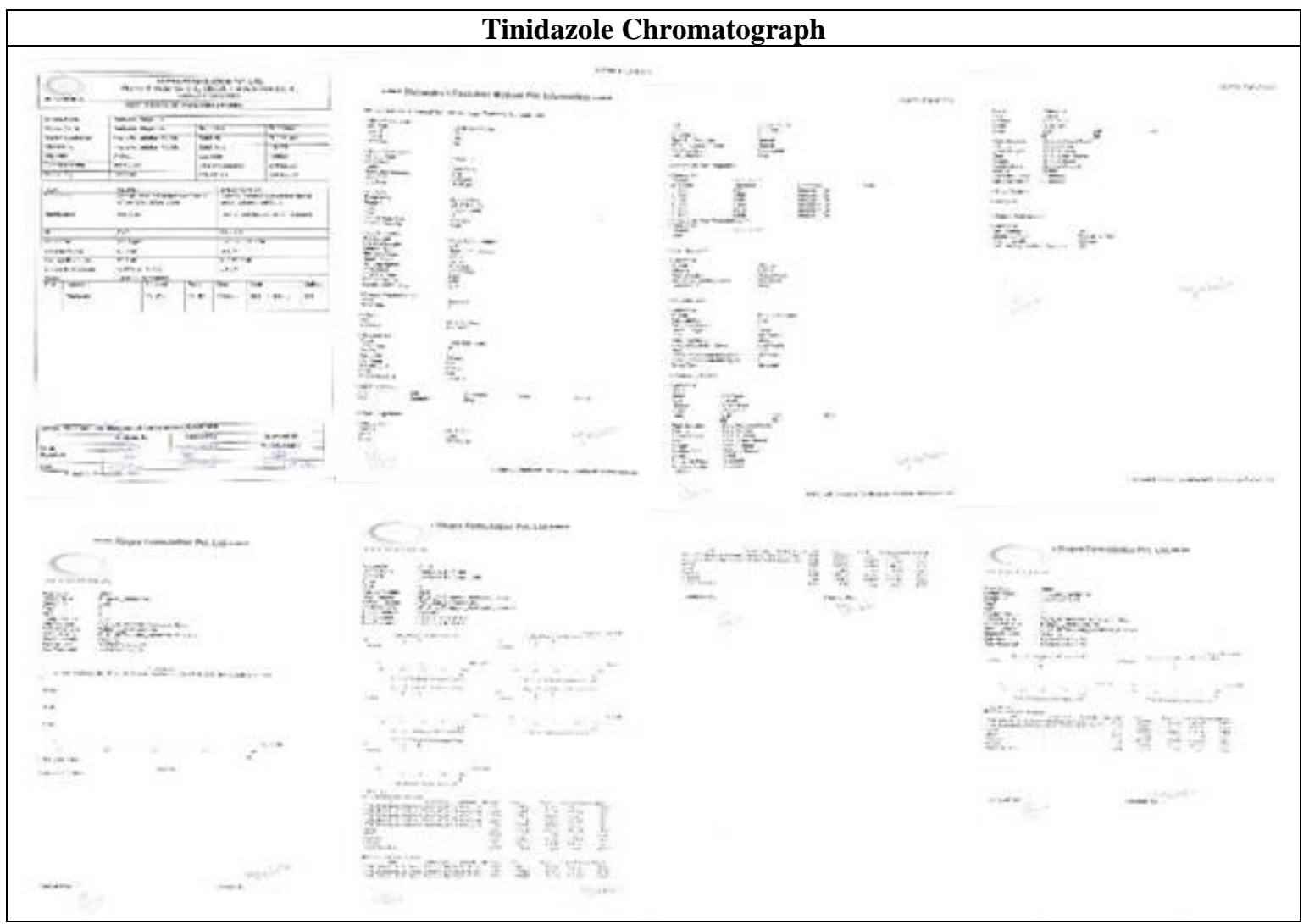

\section{DISCUSSION}

Diarrhoea among children of age 1-5 years remain a disease of high mortality and morbidity, in spite of availability of various antidiarrheal constituting antimicrobial and antiprotozoal agents. FDA approved more than 20 brands constituting Norfloxacin and Metronidazole since last 20 years without any adversity due to Norfloxacin while patients present with post diarrhoeal sequel due to disparity of biological half-life causing higher dose of Norfloxacin or lower dose of Metronidazole. Present study of evaluation of composite of Norfloxacin 100mg and Tinidazole 100mg every $5 \mathrm{ml}$ in children of age group 1-5 years shows no adversity among the patients. [2 -11]

Diarrhoea, usually a symptom of intestinal tract infection or intoxication is a second leading cause of death in children i.e. 1.7-5 million death per year common in developing country and usually, infection is caused by virus, bacteria, protozoa and parasites. $[12,13]$ Commonly prescribed antidiarrheal consist of potent antiprotozoal and antibacterial combination irrespective of age considering protozoal infection a common associate but considering diarrhoea etiopathogenesis. [14-16]

Alteration in Sodium potassium ATPase activity decreases intestinal absorption and increases intestinal mucosal secretion resulting in increased intestinal bulk and irritation of intestinal mucosal nerve ends causing hyperperistalsis presenting as lose motion and electrolyte and water loss. Antiprotozoal and antibacterial are prescribed to combat infection and super infection, as normal commensal become pathogenic due to migration from its normal site.

Clinical superiority of Tinidazole - Norfloxacin can be explained as [21-27] Ornidazole a nitro group of drug reduced by redox protein to reactive nitro radicals, which produces cytocidal action by destabilizing DNA helix and possess high volume distribution. Norfloxacin is absorbed very slowly and possess low volume distribution and protein binding thus remain longer in the GIT, facilitate longer action on intestinal pathogen ensuring early recovery and cure without any untoward effects.in addition concentration of norfloxacin ensure complete check on migrated normal commensal Escherichia coli and prevent post diarrheal UTI.

Norfloxacin never binds with DNA but binds with substrate DNA, while other quinolones acts on DNA, poses combined toxicity and hazards commonly observed by patients of either age. Tinidazole is nitro imidazole, which has broad spectrum anti protozoal activity and some anaerobic bacteria. Its selective toxicity to anaerobic microbes enters the cell by diffusion .Nitro group of drug is reduced by redox proteins present only in anaerobic organisms to reactive nitro radical which exerts cytotoxic 
action by DNA helix destabilization \&strand breakage. Thus still Norfloxacin -Tinidazole combination remains best option as antidiarrheal

\section{CONCLUSION}

Composite of Norfloxacin and Tinidazole $100 \mathrm{mg} / 5 \mathrm{ml}$ in dose of $10 \mathrm{mg} / \mathrm{Kg}$ every 12 hours in children of 1-5 years in management of diarrhoea of varied clinical severity, dehydration status and etiopatho genesis proves worth without any untoward effects either suggestive of Norfloxacin Or Tinidazole. Composite assures molecular stability at par with separate solution of Norfloxacin and Tinidazole.

\section{REFERENCES}

[1] Gupta P, Murali MV, Seth A. Epidemiology of diarrhea in urban slums. Indian Pediatr. 35 (1998): 14751. [PubMed]

[2] "The Treatment of Diarrhea, A manual for physicians and other senior health workers" (PDF). Sometimes needs to be downloaded twice. See "4.2 Treatment Plan A: home therapy to prevent dehydration and malnutrition," "4.3 Treatment Plan B: oral rehydration therapy for children with some dehydration," and "4.4 Treatment Plan C: for patients with severe dehydration" on pages 8 to 16 (12-20 in PDF). See also "8.

[3] Management of Diarrhoea with Severe Malnutrition" on pages 22-24 (26-30 in PDF) and "Annex 2: Oral and Intravenous Rehydration Solutions" on pages 33-37 (37-41 in PDF). World Health Organization. 2005. Archived (PDF) from the original on 19 October 2011

[4] Shankar ,A etal ; Comparative evaluation of norfloxacin - Tinidazole versus Norfloaxcin _ metronidazole in management of pediatric diarrhea, TheAntisepic Vol 97,No; $10\{357-359 /: 2000$

[5] Portnoy BL, DuPont HL, Pruitt D, Abdo JA, Rodriguez JT. Antidiarrheal agents in the treatment of acute diarrhea in children. JAMA. 1976 Aug 16;236(7):844-846. [PubMed]

[6] Shankar A etal ; Norfloxacin in management of Cholera ,presented at International conference of diarrhoeal disease

[7] Shankar A; Norfloxacin and Tinidazole combination in management of Diarrhea ,presented at IMA national conference 1993 at Calicut ,Published in Current Medical Practice

[8] Shankar A ,Nalidixic acid and metronidazole combination in management of diarrhoea , presented at IMA conference Dhanbad 1985 , published in Current Medical Practice

[9] World Health Organization. Diarrhea: Why children are still dying and what can be done. Geneva: World Health Organization; 2009. p. 58. Available from: http://www.whqlibdoc.who.int/publications/2009/9789 241598415_eng.pdf. [Google Scholar]

[10] Bbaale E. Determinants of diarrhea and acute respiratory infection among under- fives in Uganda. [Last accessed on 2014 Nov 10];AMJ. 2011 4(7):400-9. Available from: http//www.dx.doi.org/10.4066 /AMJ .2011.723 . [PMC free article] [PubMed] [Google Scholar]

[11]Park K. Park's Textbook of preventive and social medicine. 21st ed. Jabalpur, India: Banarasidas Bhanot Publishers; 2011. p. 528. [Google Scholar]

[12] Singh A, Singh MN. Diarrhea and acute respiratory infections among underfive children in slums: Evidence from India [online] [| CCBY3.0 Open Access | received: 19 Jan 2014, published: 19 Jan 2014. Retrieved from: https://www.peerj.com/preprints/208v1.pdf . Available from: PrePrinthttp://www.dx.doi.org/ 10. 728 7/peerj.preprints.208v1.

[13] Shah SM, Yousafzai M, Lakhani NB, Chotani RA, Nowshad G. Prevalence and correlates of diarrhea. Indian J Pediatr. 2003;70:207-11. [PubMed] [Google Scholar]

[14] Stanly AM, Sathiyasekaran BW, Palani G. A population based study of acute diarrhea among children under 5 years in a rural community in South India. Sri Ramchandra J Med. 2009;1:1-7. [Google Scholar]

[15] Siziya S, Muula AS, Rudatsikira E. Diarrhea and acute respiratory infections prevalence and risk factors among under-five children in Iraq in 2000. Ital J Pediatr. 2009;35:1-9. [PMC free article] [PubMed] [Google Scholar]

[16] Kumar N, Gupta N, Kishore J. Kuppuswamy's socioeconomic scale: Updating income ranges for the year 2012. Indian J Public Health. 2012;56:103-4. [PubMed] [Google Scholar]

[17] Narain JP, Banerjee KB. Epidemiology of ARI acute respiratory infections. Indian J Pediatr. 1987;54:15360. [PubMed] [Google Scholar]

[18] Tivari SC, Saraf Y, Nambiar G. Study of diarrheal diseases in 0-5 years old children and practices of oral rehydration solution, Bhopal, Madhya Pradesh in Conference Proceedings of the 9th Asian conference on diarrheal diseases and nutrition; Sep 28-30, 2001; New Delhi. [Google Scholar]

[19] Ansari MA, Khan Z, Khan IM. A clinico social study to assess the magnitude of diarrheal diseases among children in rural areas of Alligarh, Uttar Pradesh in Conference Proceedings of the 9th Asian conference on diarrheal diseases and nutrition; Sep 28-30, 2001; New Delhi. [Google Scholar] 
[20] Mtike G. Prevalence of acute and persistent diarrhea in North Gondar zone, Ethiopia. East Afr Med J. 2001;78:433-8. [PubMed] [Google Scholar]

[21] Alshehri M, Abdelmoneim I, Gilban HM. Analysis of diarrhea episodes in children reported at a primary health care centre in Abha city in the year 2002. J Family Community Med. 2004;11:35-8. [PMC free article] [PubMed] [Google Scholar]

[22] Scrinshaw NS. Historical concepts of interactions, synergism and antagonism between nutrition and infection. J Nutr. 2003;133:316S-21. [PubMed] [Google Scholar]

[23] Siziya S, Mulla AS, Rudatsikira E. Diarrhea and acute respiratory infections prevalence and risk factors among under-five children in Iraq in 2000. Ital J Pediatr. 2009;35:1-9. [PMC free article] [PubMed] [Google Scholar]

[24] Mengistie B, Berhane Y, Worku A. Prevalence of diarrhea and associated risk factors among children under five years of age in estern Ethopia. A cross-sectional study. Open J Prev Med. 2013;3:446-53. [Google Scholar]

[25]Desalegn M, Kumie A, Tefera W. Predictors of under-five childhood diarrhea: Mecha District, West Gojjam, Ethiopia. Ethiopian Journal of Health Development. 2011;25:174-232. [Google Scholar]

[26] Boadi KO, Kuitunen M. Childhood diarrheal morbidity in the Accra Metropolitan Area, Ghana: Socioeconomic, environmental and behavioral risk de- terminants. Journal of Health and Population in Developing Countries. Available from: http://www.jhpdc.unc.edu/

[27] Dewey KG, Adu-Afarwuah S. Systematic review of the efficacy and effectiveness of complementary feeding interventions in developing countries. Matern Child Nutr. 2008 4(Suppl 1):24-85. Available from: http://www.dx.doi.org/10.1111/j.1740-8709.2007.00124.x . [PMC free article] [PubMed] [Google Scholar]

Citation: Dr Avinash Shankar et.al., (2020). "Norfloxacin - Tinidazole Suspension in Management of Infective Paediatric Diarrhoea (1-5 Years)", International Journal of Clinical Chemistry and Laboratory Medicine (IJCCLM), 6(2), pp.1-11. DOI: http://dx.doi.org/10.20431/2455-7153.0602001

Copyright: (C) 2020 Authors, This is an open-access article distributed under the terms of the Creative Commons Attribution License, which permits unrestricted use, distribution, and reproduction in any medium, provided the original author and source are credited. 